\title{
Bulanık Mantık Esaslı Karar Destek Sistemi ile Robot Elin Kuvvet Kontrolü
}

\section{Fuzzy Logic Based Decision Support System for Force Control of Robot Hand}

\author{
Çağlar Conker ${ }^{*}\left(\mathbb{0}\right.$, Aslıhan Karaca2 ${ }^{\circledR}$ \\ 1 İskenderun Teknik Üniversitesi, Mühendislik ve Doğa Bilimleri Fakültesi, Mekatronik Mühendisliği Bölümü, Hatay \\ 2 İskenderun Teknik Üniversitesi, Mühendislik ve Doğa Bilimleri Fakültesi, Makine Mühendisliği Bölümü, Hatay \\ Sorumlu Yazar / Corresponding Author*: caglar.conker@iste.edu.tr
}

Geliş Tarihi / Received: 23.10 .2018

DOI:10.21205/deufmd.2019216210

Kabul Tarihi / Accepted: 22.01.2019

Arastırma Makalesi/Research Article

Atıfșekli/How to cite: CONKER, C.., KARACA, A. (2019). Bulanık Mantık Esaslı Karar Destek Sistemi ile Robot Elin Kuvvet Kontrolü. DEUFMD,

21(62), 433-447.

Öz

Son yıllarda gelişen teknoloji ile robotlar üzerine yapılan çalışmaların ciddi oranda arttığı gözlenmektedir. Robotik sistemlerde robot el konusu, farklı ihtiyaçlar doğrultusunda farklı kullanım alanlarına yönelik olarak gelişmeye en açık çalışma alanlarından birisidir. Literatür çalışmaları incelendiğinde, robot el uygulamalarında karșılașllan en büyük sorunun nesnelerin kavranma kuvvetinin kontrolü olduğu tespit edilmiștir. Bu sebeple robot elin nesnelere zarar vermeden kavrama işlemini gerçekleştirebilmesi için kavrama kuvvetinin kontrol sorunu çözülmelidir. Sunulan çalıșmada nesnelere uygulanan kuvvetin kontrol probleminin çözümü için yapay zeka tekniklerinden biri olan bulanık mantık önerilmiştir. Önerilen yöntemde, robot el kavrama kuvvetini kullanıcının gönderdiği sinyal doğrultusunda belirlemektedir. Sistemin avuç içerisinde ve parmaklarının iç kısımlarında bulunan sensörler vasıtasıyla nesnelere uygulanan kuvvet ölçülmekte ve bu sensör ölçümleri kuvvet geri beslemesi olarak kullanılmaktadır. Ölçülen sensör verileri ve kullanıcı sinyali bulanık mantık kontrolör(karar destek sistemi) ile denetlenerek nesnenin kontrol sistemi tarafından belirlenen kuvvette stabil bir şekilde kavranması sağlanmaktadır. Geliştirilen kontrol yapısı oluşturulan sistemde uygulanmış ve kullanıcıdan gönderilen komut doğrultusunda hassas ve kararlı kavrama yapabildiği sunulan çalışma ile gösterilmiştir.

Anahtar Kelimeler: Bulanık mantık, Karar destek sistemi, Robot el, Akıllı sistem, Robotik sistemler

\begin{abstract}
In recent years, it is observed that the studies on robotic systems have increased tremendously. In the field of robotic systems, the robotic hand based research is one of the most popular fields due to wide range of application areas. It can be observed from a literature review of robot hand applications is that one of the main research topic in the area is on control of gripping force of the objects. Hence, the force feedback problem appears to be a challenge to be overcomed where the objective is to perform the grasping operation without damaging the objects being hold. In this study, Fuzzy Logic based artificial intelligence techniques has been proposed as a solution of the problem of force control problem mentioned. In proposed method, the robot hand determines the grip force by the direction of the signal sent by the user. The force applied to the objects is measured by the sensors. These sensor measurements are then used as force feedback. The
\end{abstract}


measured sensor data and the user input signals are controlled by a fuzzy logic control system (decision support system) to ensure that the object is grasped in a stable manner. The developed control structure is implemented and it proven that the user is able to grasp sensitively and decisively by the direction of the control command sent by the user.

Keywords: Fuzzy logic, Decision support system, Robot hand, Smart systems, Robotic systems

\section{Giriș}

Günümüzde robotik sistemlerin kullanımıyla birlikte, üretimde oluşabilecek insan hata payı ve kaza oranının düşürülmesi sağlanmaktadır. Endüstriyel yapıdaki robotların geliștirilmesinde, insansı robotlar üzerine yoğunlaşılmasını takiben üretimde: kalite, verimlilik ve robotların kontrol hassasiyeti her geçen gün artmaktadır. $\mathrm{Bu}$ doğrultuda robot manipülatörlerin insan eli yapısına olan benzerliklerinin arttığı ve bu konu üzerinde çalışmaların yoğunlaştığ gözlemlenmektedir[1]. Yapılan çalışmalar, elektronik/mekanik tasarımların iyileștirilmesini, hassas hareket ve kuvvet kontrollerinin yapılmasını veya mevcut yapıların geliștirilmesini gerekli kılmaktadır. Robot manipülatörler; üretimden araștırmaya, askeri alandan protez olarak kullanıma kadar çok geniş kullanım alanına sahiptir [1]. Bu nedenle farklı ihtiyaçlar doğrultusunda farklı kullanım alanlarına yönelik gelişmeye en açık çalışma konularından birisidir. Robot manipülatörler üzerine geçmişten bugüne birçok çalışma yapılmış ve araştırma, geliştirme çalışmaları artarak devam etmiştir. İncelenen ve önemli olduğu düşünülen çalışmaların bir kısmı kronolojik sırayla Tablo 1'de sunulmaktadır.

Manipülatörlerin nesneye uyguladıkları kuvvetin hassas kontrol edilememesi sebebiyle kavranan nesnenin zarar görmesi, çözülmesi gereken önemli bir problemdir. Tablo 1'e bakıldığında robot ellerde kuvvet kontrolüne ve nesnelerin en uygun biçimde kavranmasına yönelik birçok çalıșma yapılmıștır. Ayrıca robot ellerin kontrolünün hassaslaştırılmasına yönelik çalışmalara devam edilmektedir. Robot manipülatörler çok girdili ve çok çıtıtılı yapıya sahip sistemlerdir. Bu tip sistemlerin doğrusal bir modeli oluşturularak kontrol edilmesi oldukça güçtür[2,3]. Robot manipülatörlerden biri olan robot el ile nesnelere dokunmak, tutmak, nesnelerin deforme olmasını gözardı ederek kavrama işlemini gerçekleştirmek ve bu hareket formları oluşturulurken kuvvet sensörlerinden alınan geri bildirimler de kullanılarak hareket profillerinin oluşturulması ya da matematiksel modellemeler kullanılarak bu çok girdili sistemlerin kontrolü oldukça karmaşık bir konudur[3,4,5]. Tabloda bulunan literatür çalışmaları incelendiğinde; robot ellerin nesneleri kavraması sırasında hareket ve nesnelere uyguladıkları kuvvetin kontrolü; matematiksel çözümlemelerin yanı sıra, PID, PD, PI, makine öğrenmesi, empedans kontrol gibi kontrol yöntemleri kullanılarak veya farklı kontrol algoritmalarıyla sağlanmıştır. Robot el için doğrusal model oluşturmanın güç olması sebebiyle mevcut olan sistemlerdeki kuvvet geri besleme sorununa yönelik önerilen çözüm yolları karmaşı ve kontrol stratejisinin geliştirilmesi zordur[2,6]. Sunulan çalışmada, kuvvet geri besleme sorununun olabildiğince basit ve hassas bir şekilde çözüme kavuşturulması amaçlanmıştır. $\mathrm{Bu}$ amaç doğrultusunda sunulan çalışmada kuvvet kontrolünde matematiksel ifadeleri, dilsel ifadelerle temsil etmesi ve sezgisel uygulamalarda iyi sonuçlar vermesi sebebiyle yapay zeka tekniklerinden biri olan bulanık mantık kullanılarak, bulanık mantık temelli bir kontrolcü geliştirilmiştir. Bulanık mantık kontrol sisteminin robot eli kontrolü sırasında değerlendirmede kullanacağı referans değer kullanıcı tarafından bir potansiyometre aracılığla gönderilmektedir. $\mathrm{Bu}$ sayede geliştirilen kontrol sistemi ile kullanıcı temelli hassas kuvvet kontrolü yapilabilmektedir. Kontrol sistemi robot elde test edilmiş ve kullanıcının istediği kavrama kuvvetinin kontrolü sağlanmıștır. Robot elin her bir parmağı, kullanıcı tarafından gönderilen tek bir kontrol sinyaline göre nesneye uyguladığı kuvveti birbirinden bağımsız bir şekilde kontrol etmektedir. $\mathrm{Bu}$ sayede robot elin parmakları kavranan nesnenin șekline göre adaptif bir șekilde hareket edebilmektedir. Sağlanan kuvvet ve hareket kontrolü vasitasıyla robot elde oluşabilecek kontrol yetersizliği sonucu nesnelerin zarar görmesi önlenebilecektir. Geliştirilen kontrol sistemi karmaşıklıktan uzak, geniş uygulama alanına ve hassas sonuçlar verebilen bir yapıya sahiptir. 
DEU FMD 21(62), 433-447, 2019

Tablo 1. Literatür tablosu

\begin{tabular}{|c|c|c|c|}
\hline & Çalışmanın içeriği & Çalışmanın görseli & Mekanik özellikleri \\
\hline 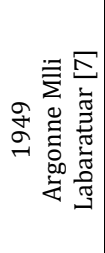 & $\begin{array}{l}\text { Yapılan çalışma ile laboratuvar ortamında } \\
\text { radyoaktif malzemeleri işlemek için mekanik } \\
\text { manipülatör geliştirilmiștir. İlk uzaktan kontrollü } \\
\text { robotik el, efendi-köle tipindedir. Efendi } \\
\text { manipülatöre kullanıcı tarafından bir dizi hareket } \\
\text { verilmekte, köle olan manipülatör ise bu } \\
\text { hareketleri mümkün olduğu kadar hızlı takip } \\
\text { etmektedir. }\end{array}$ & & $\begin{array}{l}\text { Çubuk mekanizmaları } \\
\text { ile, yarı üniversal } \\
\text { eklemler ve pençe } \\
\text { benzeri el yardımıyla } \\
\text { kavrama } \\
\text { sağlanmaktadır. }\end{array}$ \\
\hline 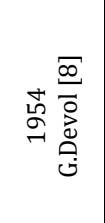 & $\begin{array}{l}\text { Geliştirilen cihaz; bir dizi hareket adımlarından } \\
\text { oluşan işlemleri (belirli bir konumda bulunan bir } \\
\text { nesneyi kavrayıp, belirlenen bașka konuma } \\
\text { bırakmak gibi) program içerisindeki komutlar } \\
\text { tarafindan gerçekleștirmektedir. Bu cihaz; tarihte } \\
\text { geliștirilen ilk programlanabilir elektromekanik } \\
\text { manipülatör olarak kabul edilmektedir. }\end{array}$ & & - \\
\hline 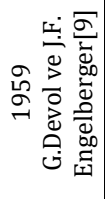 & $\begin{array}{l}\text { Bu çalışmada bir manipülatörün, bilgisayar ile } \\
\text { uyumlu çalışması sağlanmıştır. Bunun sonucunda } \\
\text { birçok farklı görev otomatik olarak } \\
\text { gerçekleştirilmiştir. Bu çalışma ile ilk endüstriyel } \\
\text { robotlara öncülük edilmiştir. }\end{array}$ & & - \\
\hline 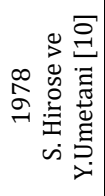 & $\begin{array}{l}\text { Mekanik yapısı sayesinde nesneyi şekline göre } \\
\text { adaptif şekilde kavrayabilen yumuşak tutucu } \\
\text { geliştirilmiştir. Bir motor ile kontrol edilen bu } \\
\text { prototip bağlantı kasnakları vasıtasıla kuvvetleri } \\
\text { dağıtmaktadır. Üniform basınç ile her şekildeki } \\
\text { nesneyi tutabilmektedir. }\end{array}$ & & $\begin{array}{l}\text { Her bir mafsalı bir } \\
\text { serbestlik derecesine } \\
\text { sahip sistemin bağlantı } \\
\text { kasnakları ile güç } \\
\text { iletimi sağlanmaktadır. }\end{array}$ \\
\hline 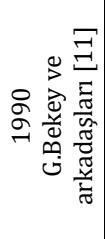 & $\begin{array}{l}\text { Yapılan çalışmada; kavramadan önce hedef } \\
\text { nesnenin konumu, yönü ve geometrisi görüş } \\
\text { sisteminden alınan veriler ile birleştirilmektedir. } \\
\text { Kontrol algoritması; görev bilgisi ile istenilen } \\
\text { kavrama modunu üretir ve hedef kuvvete gelinceye } \\
\text { kadar parmaklar kapatılır. Bu sayede insan eline } \\
\text { benzer adaptif kavrama sağlanmaktadır. }\end{array}$ & & $\begin{array}{l}5 \text { parmaklı belgrade el, } \\
\text { dört motorlu bir tutu- } \\
\text { cudur. Her parmak çifti } \\
1 \text { serbestlik derecesine } \\
\text { ve başparmağ } 2 \\
\text { serbestlik derecesine } \\
\text { sahiptir. }\end{array}$ \\
\hline 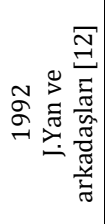 & $\begin{array}{l}\text { Bu çalışma da sensörlerden gelen veriler geri } \\
\text { beslemede kullanılarak robot kol ve elin; pozisyon } \\
\text { ve kuvvet uyum kontrol sistemi geliştirilmiştir. } \\
\text { Geliştirilen kontrol sistemiyle; robot kolun } \\
\text { kinematik denklemleri ile kolun pozisyon uyum } \\
\text { planlaması ve elin kuvvet uyum planlaması } \\
\text { sağlanmıştır. }\end{array}$ & & $\begin{array}{l}2 \text { serbestlik derecesine } \\
\text { sahip } 2 \text { parmaklı } \\
\text { tutucu tasarlanmıștır. }\end{array}$ \\
\hline 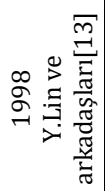 & $\begin{array}{l}\text { Tasarlanan } 17 \text { serbestlik derecesine sahip elin her } \\
\text { bir eklemi ayrı ayrı kontrol edilebilmektedir. } \\
\text { Uygulanan algoritma ile simülasyonda çokgen ve } \\
\text { silindir şeklindeki nesnelerin en uygun pozisyon } \\
\text { için temas noktaları seçilmesi sağlanmıştır. }\end{array}$ & & $\begin{array}{l}5 \quad \text { parmaklı elin } \\
\text { bașparmak ve işaret } \\
\text { parmağı 4'er, diğer } \\
\text { parmakları } r \text { 'er } \\
\text { serbestlik derecesine } \\
\text { sahiptir. }\end{array}$ \\
\hline
\end{tabular}


DEU FMD 21(62), 433-447, 2019

\begin{tabular}{|c|c|c|c|}
\hline 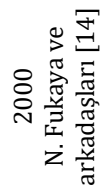 & $\begin{array}{l}\text { Yapılan çalışmada geliştirilen elin bütün } \\
\text { parmakları aynı kuvveti uygulayabilmekte ve } 6 \\
\text { temel tutma işlevini yerine getirebilmektedir. } \\
\text { Tasarımın kavrama deneyleri sonucunda insan } \\
\text { elinin kavrama biçimlerinden çok küçük sapmalar } \\
\text { gözlemlenmiştir. }\end{array}$ & & $\begin{array}{l}\text { Tasarlanan el; } 5 \\
\text { parmaklı ve } 20 \\
\text { serbestlik derecesine } \\
\text { sahiptir. Elde hareket } \\
\text { iletimi tendonlarla } \\
\text { sağlanmaktadır. }\end{array}$ \\
\hline 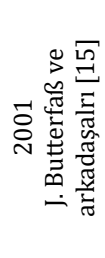 & $\begin{array}{l}\text { Manipülatör harici bir bilgisayar ile seri } \\
\text { haberleşme yaparak kontrol edilmektedir. } \\
\text { Sensörlerden gelen veriler ve bilgisayardan gelen } \\
\text { veriler doğrultusunda nesneye uygun kavrama } \\
\text { sağlayabilmektedir. Parmakların kartezyen } \\
\text { empedans kontrolü yapılmıştır. Empedans } \\
\text { kontrolünde hatayı düşürmek için PI kontrol } \\
\text { uygulanmıştır. }\end{array}$ & & $\begin{array}{lr}13 & \text { serbestlik } \\
\text { derecesine } & \text { sahip } 4 \\
\text { parmaklı robotik elin, } \\
\text { hareket r iletimi } \\
\text { eklemlerde bulunan } \\
\text { dișliler r ile } \\
\text { sağlanmaktadır. }\end{array}$ \\
\hline 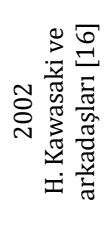 & $\begin{array}{l}\text { Manipülatör bilgisayar tabanlı robot el kumandası } \\
\text { ile kontrol edilmiştir. Eklem, bağlantı pozisyonu ve } \\
\text { temas kuvveti ile hibrit bir kontrol sistemi } \\
\text { sağlanmıştır. Temas olmadığı durumda PID kontrol } \\
\text { eklem pozisyon kontrolüne uygulanmış ve temas } \\
\text { durumunda pozisyon ve kuvvetin hibrit kontrolü } \\
\text { gerçekleştirilmiştir. }\end{array}$ & & $\begin{array}{l}\text { Tasarlanan elin toplam } \\
20 \text { eklemi ve } 16 \\
\text { serbestlik derecesi } \\
\text { bulunmaktadır. Güç } \\
\text { iletimi dişliler ile } \\
\text { sağlanmaktadır. }\end{array}$ \\
\hline 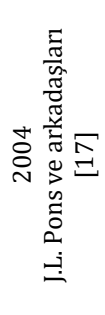 & $\begin{array}{l}\text { Yapılan çalışma ile kullanıcı; parmak hareketlerini } \\
\text { EMG sensörü ile kontrol etmektedir. PID kontrolle } \\
\text { konum ve kuvvet sensörlerinden gelen verileri } \\
\text { işleyip parmağın uyguladığı tork ayarlanmaktadır. } \\
\text { Başparmakta bulunan genova mekanizması ile } 2 \\
\text { eksenli mafsalın hareketlerinin yönlendirilmesi bir } \\
\text { motorla yapılmaktadır. Ayrıca önerilen empedans } \\
\text { kontrol yaklașımı, parmakların sanal yaylar gibi } \\
\text { hareket etmesini sağlamaktadır. }\end{array}$ & & $\begin{array}{lr}10 & \text { serbestlik } \\
\text { derecesine } & \text { sahip } 5 \\
\text { parmaklı el } & \text { tasarımı } \\
\text { yapılmıştır. } & \text { Başpar- } \\
\text { makta } & \text { genova } \\
\text { mekanizması } & \\
\text { kullanılmıstır. } & \text { 4. ve } 5 . \\
\begin{array}{l}\text { Parmaklar } \\
\text { olarak }\end{array} & \text { manuel } \\
\text { bükülebilmektedir. }\end{array}$ \\
\hline 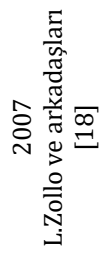 & $\begin{array}{l}\text { Parmakların eklem açısı, tendon gerginliği ve } \\
\text { motor hareketi PD kontrolcü ile sağlanmıştır. } \\
\text { Yapay elin mekanik tasarımını, el kontrol } \\
\text { sisteminin tasarımı ile uyumlu hale getirmek ve } \\
\text { insan elinin kinematik ve dinamik yapısına benzer } \\
\text { el tasarımı yapılabilmesi için biyomekatronik } \\
\text { yaklaşımla elin tasarımının ve kontrol sisteminin } \\
\text { optimizasyonu üzerinde durulmuştur. }\end{array}$ & & $\begin{array}{l}3 \text { parmaklı elin, baș } \\
\text { parmağı } 4 \text { diğer } \\
\text { parmakları } 3 \text { serbestlik } \\
\text { derecesine sahiptir. } \\
\text { Parmaklardaki bütün } \\
\text { eklemler mafsallar ile } \\
\text { birbirine bağlıdır. }\end{array}$ \\
\hline 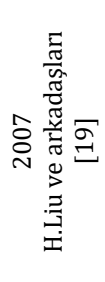 & $\begin{array}{l}\text { Çalışmada } 5 \text { aşamalı modüler kontrol sistemi } \\
\text { geliştirilmiş ve uygulanmıştır. Kontrol sistemi; } \\
\text { düşük seviyeli kontrol aşaması, parmaktaki } \\
\text { dataların işlemesi, eldeki dataların işlemesi, yüksek } \\
\text { seviyeli kontrol ve dış kumanda aşamasından } \\
\text { oluşmaktadır. Sistem test edildiğinde kendi } \\
\text { kendine kavramada ve tele-operasyon } \\
\text { denemelerinde kontrol mimarisi elin kontrolünde } \\
\text { başarı göstermiștir. }\end{array}$ & & 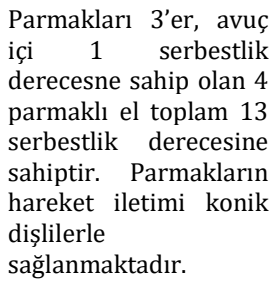 \\
\hline
\end{tabular}


DEU FMD 21(62), 433-447, 2019

\begin{tabular}{|c|c|c|c|}
\hline 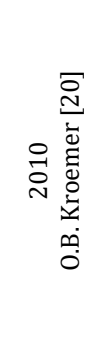 & $\begin{array}{l}\text { Yapılan çalışmada çeşitli makine öğrenmesi } \\
\text { metotları kullanılarak kavrama işlemi için } \\
\text { hiyerarşik yapıda aşamalı hibrit denetleme } \\
\text { sunulmuştur. Yüksek seviye kontrolör; obje } \\
\text { kavramalarında takviyeli öğrenme kullanarak } \\
\text { nereden kavrayacağına karar verirken, düşük } \\
\text { seviyeli kontrolörde taklit öğrenme ve görme } \\
\text { temelli reaktif kontrolör sayesinde uygun kavrayış } \\
\text { hareketlerini seçmektedir. Oluşturulan sistem ile } \\
\text { yeni bir nesnenin kavranması hızlı bir şekilde } \\
\text { öğrenilebilmektedir. }\end{array}$ & & $\begin{array}{lr}\text { Bu çalışmada tasarım } \\
\text { yapılmamıştır. } & 7 \\
\text { serbestlik derecesine } \\
\text { sahip Mitsubishi kol ve } \\
\text { barrett } \\
\text { kullanılmıştır. }\end{array}$ \\
\hline 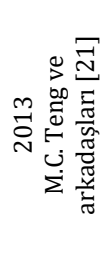 & $\begin{array}{l}\text { Çalışmada ters kinematik çözümleme ile kontrol } \\
\text { algoritması uygulanmıştır. İstenen hareketi } \\
\text { gerçekleştirmek için ters kinematik çözümleme ve } \\
\text { referans konum kullanılarak robot manipülatör } \\
\text { kontrol edilmektedir. } \\
\text { özelliklerinin tanınması ve } \\
\text { sağlanarak harenet kontrolü } \\
\text { gerçekleştirilmektedir. }\end{array}$ & & $\begin{array}{l}\text { Bu tasarım; elin } 4 \text { ve } \\
\text { kolun } 6 \text { olmak üzere } \\
\text { toplam } 10 \text { serbestlik } \\
\text { derecesine sahiptir. } \\
\text { Parmaklara güç iletimi } \\
\text { tendonlar ile } \\
\text { yaplmaktadır. }\end{array}$ \\
\hline 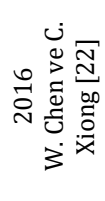 & $\begin{array}{l}\text { Çalışmada adaptif kavrama için konum ve kuvvet } \\
\text { değişimine dayanan yeni bir yöntem sunulmuştur. } \\
\text { Hareket kuvvetlerinin gelişimi incelenerek bir } \\
\text { analiz yöntemi geliştirilmiş, geliştirilen analiz } \\
\text { yöntemiyle kavranan farklı nesnelere güvenli ve } \\
\text { adaptif kavrama sağlanmıştır. }\end{array}$ & & $\begin{array}{l}\text { Testlerde kullanılan } \\
\text { elin kuvvet iletimi } \\
\text { tendonlarla } \\
\text { sağlanmaktadır. El } 5 \\
\text { parmak ve } 16 \text { ekleme } \\
\text { sahiptir. }\end{array}$ \\
\hline 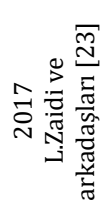 & $\begin{array}{l}\text { Bu çalışmada deforme olan cisimleri } \\
\text { kavrayabilmek için model tabanlı bir strateji } \\
\text { geliştirilmiştir. Deforme olan nesne kavranmaya } \\
\text { başladığında fark edilerek, nesne-parmak deforme } \\
\text { hesabı yapılmaktadır. Böylece kuvvet kontrolü ile } \\
\text { nesneye zarar vermeden } \\
\text { sağlanabilmektedir. }\end{array}$ & & $\begin{array}{l}\text { Bu çalışmada tasarım } \\
\text { yapılmamıştır. Hazır } \\
\text { Kuka LWR4 ve Shadow } \\
\text { el kullanılmıştır. }\end{array}$ \\
\hline 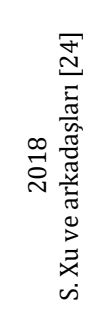 & $\begin{array}{l}\text { Yapılan çalışmada; farklı robot platformlarına } \\
\text { uyarlanabilir bir robot el tasarlanmıştır. Parmak } \\
\text { ucunun pozisyonunu elde etmek için bir kinematik } \\
\text { model oluşturulmuş ve robot elinin hareket } \\
\text { yörüngesi ve kavrama alanı çözülmiştür. Sisteme } \\
\text { farklı robot platformlarında farklı görevler } \\
\text { verilmiştir. Sistem yapılan deneylerde yaklaşık } 10 \\
\text { farklı kavrama görevini gerçekleştirebilmiş, farklı } \\
\text { robot platformlarında uyumlu bir şekilde } \\
\text { çalıșabilmiştir. }\end{array}$ & & $\begin{array}{l}\text { Tasarımı yapılan el } 5 \\
\text { parmaklı ve baş } \\
\text { parmağı } 4 \text { diğer } \\
\text { parmakları } 3 \text { 'er olmak } \\
\text { üzere toplam } 16 \\
\text { serbestlik derecesine } \\
\text { sahiptir. Motorlardan } \\
\text { parmaklara hareket ve } \\
\text { güç iletimi tendonlarla } \\
\text { sağlanmakatadır. }\end{array}$ \\
\hline
\end{tabular}

\section{Materyal ve Metot}

$\mathrm{Bu}$ bölümde robot elin mekanik yapısı, sensör verilerinin işlenmesi ve sistemin elektronik ve elektromekanik donanım yapısı sunulmaktadır.

\subsection{Robot elin mekanik yapısı}

Çalışmada 5 parmaklı robot el kullanılmıştır. 17 serbestlik derecesine sahip robot elin; baș, işaret ve orta parmakları 3'er serbestlik derecesine sahiptir. Yüzük ve serçe parmakları ise avuç içinde kısmen hareket yapabilmelerini sağlayan eklemlerle 4'er serbestlik derecesine sahiptir. Parmaklara hareket iletimi tendonlarla sağlanmaktadır. Tendon kullanımı ile parmak eklemlerinin nesneye göre adaptif şekil alması sağlanmıştır. Tendonların hareketini sağlayan eyleyiciler ön kolda yer almaktadır. Ayrıca bilek tek serbestlik derecesine sahiptir ve hareket iletimi dişlilerle sağlanmaktadır. Elin boyutu ve yapısı, insan eli ile benzer yapıdadır.

Elin üretimi için 3 boyutlu yazıcı teknolojisi kullanılmıştır. El Akrilonitril Bütadien Stiren (ABS) malzeme ile basılmıştır. ABS kullanımı ile ucuz ve hafif bir el prototipi elde edilmiștir[25]. Basımı ve montajı yapılan el Şekil 1'de sunulmaktadır. Basımı yapilan ve deneylerde kullanılan robot el 2012 yılında Gael Langevin tarafından tasarlanmış ve açık kaynak tasarım olarak paylaşılmıştır [26]. 

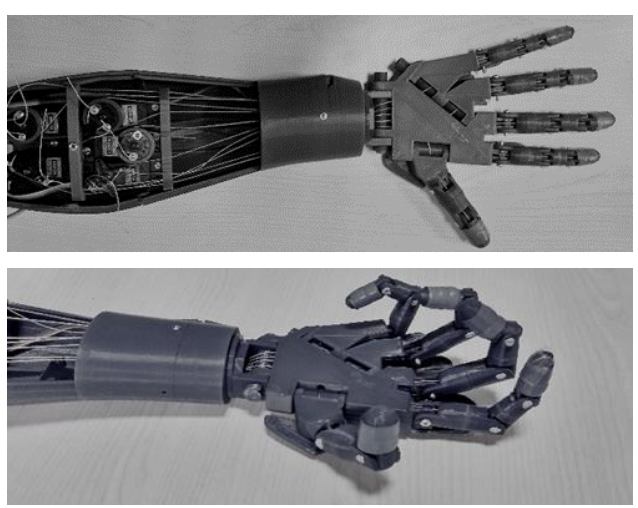

Şekil 1. Deneylerde kullanılan robot el

\subsection{Kuvvet sensörü}

FSR (kuvvete duyarlı direnç) kuvvet sensörü; aktif yüzeyine uygulanan kuvvetin artması ile dirençte azalma gösteren polimer kalın film elektronik bileșendir[27]. Sistemde İnterlink Elektroniğin FSR 402 isimli kuvvet sensörü kullanılmıștır. Kuvvet sensörü üzerine 600 grama kadar ağırlık konularak kuvvet-gerilim değişimi test edilmiştir. Kuvvet sensörüne uygulanan kuvvet miktarına göre üzerinden geçen gerilim miktarı, mikrodenetleyici ile ölçülmüştür. Sensörde üretilen değerler 0-5000 mili volt aralığındadır. Ancak mikrodenetleyici 10 bitlik analog-dijital dönüştürücüye sahip olduğu için 0-5000 mili volt aralığıyla orantılı 01023 aralığında sayısal değerler elde edilmektedir. Sensör ve direnç yardımıyla gerilim bölücü devre oluşturulmuş olup, oluşturulan devre ile kuvvet ölçümü yapılmıştır. Sensörün üzerine gelen kuvvete göre, direnç değișimi Denklem 1'de verilen matematiksel ifade ile hesaplanmıștır, devre ise Şekil 2'de sunulmuştur. Elde edilen kuvvete göre direnç değişiminin grafiği Șekil 3'te sunulmuştur.

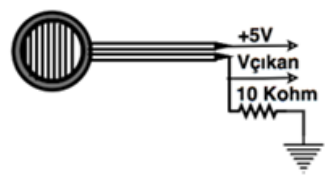

Şekil 2. Gerilim bölücü devre

$\mathrm{R} 1=\mathrm{R} 2 \times($ Vgiren - Vçıkan $) \div$ Vçıkan

Denklem 1'de: R1; kuvvet sensörü direnç degeri, R2 devrede kullanılan 2 . direnç degeri(10 k $\Omega)$, Vgiren; sensöre verilen gerilim
miktarı(5V), Vçıkan; sensörden çıkan gerilim miktarıdır.

Șekil 3'te kuvvet sensörü üzerine kuvvet uygulandığında başlangıçta direnç değişiminin çok yüksek olduğu daha sonra direnç değișiminin azalarak, direncinin düștüğü görülmektedir. Şekil 3'te sunulan grafikte direnç değişimi logaritmik olarak, kuvvet değişim miktarı ise lineer olarak verilmiştir.

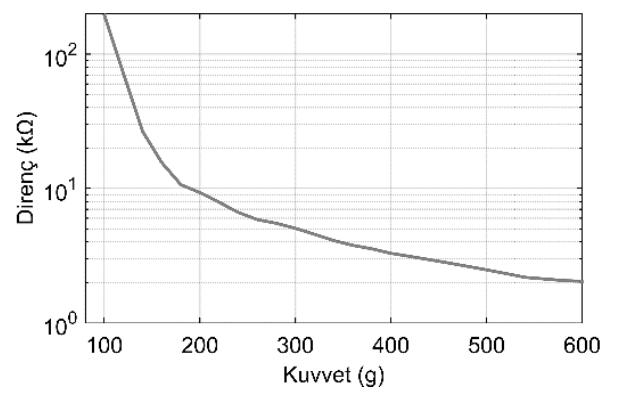

Şekil 3. Kuvvet-direnç değişim grafiği

Kuvvet sensorüne yapılan test sonuçları mikrodenetleyici tarafindan okunmuş ve elde edilen sayısal değerler eğri uydurma yöntemi ile değerlendirilmiştir. Elde edilen kuvvet egrisinin denklemi Denklem 2'de verilmiştir. Eğri uydurma yönteminde denklem elde edilirken sensörün bașlangıçta duyarsız oldugu değerler ihmal edilmiştir. Eğri uydurma yöntem çıktısı ile ölçüm sonuçları Şekil 4'te gösterilmiștir. Elde edilen denklemin, kuvvet sensörü degerlerinin değişimi ile tutarlılıga sahip olduğu gözlemlenmiştir.

$$
P=\left(-0.0024 \times x^{2}\right)+(2.7008 \times x)+81
$$

Denklem 2'de: x; ağırlık miktarıdır(gr).

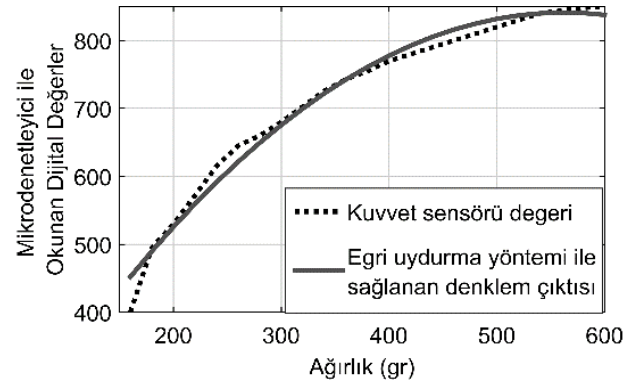

Şekil 4. Eğri uydurma yöntemi ile elde edilen grafik 
DEU FMD 21(62), 433-447, 2019

\subsection{Robot elin elektronik ve elektromekanik donanım yapısı}

Robot elin parmaklarını hareket ettirebilmek için parmaklarda bulunan misinaların sürülmesi, eyleyiciler ile sağlanmıştır. Eyleyici olarak her bir parmak için bir adet olmak üzere toplam 5 adet servo motor kullanılmıștır. Servo motorlar; 180 derece hareket kabiliyeti, kontrol kolaylığı ve konum hassasiyetinden dolayı tercih edilmiștir. Sistemde Tower Pro marka MG996R isimli servo motor kullanılmıștır. Robot elin objeleri kavrama esnasında objeye uygulanan kuvvetin ölçülebilmesi için parmak falankslarına ve avuç içine kuvvet sensörleri yerleștirilmiștir. Kuvvet sensörünün özellikleri bölüm 2.2'de tartışılmıștır. Kullanıcıdan komut gönderimi için ise 1 adet potansiyometre kullanılmıştır ve kullanıcı potansiyometre ile mikrodenetleyiciye farklı komut sinyalleri gönderebilmektedir. Robot elde sensörlerden gelen verilerin işlenmesi, servo motorların kontrol işlemleri, bilgisayar ile haberleşmenin gerçekleştirilmesi için mikrodenetleyici kullanılmıştır. Mikrodenetleyici olarak arduino uno tercih edilmiștir. Robot elin 1 parmağının elektronik ve elektromekanik sistemlerinin mikrodenetleyici ile bağlantısı Şekil 5'te gösterilmektedir. Robot elin hareket ve kuvvet kontrolü oluşturulan kontrolcü sistem üzerinden, bilgisayar ve mikrodenetleyicinin seri haberleșmesi ile kontrol edilmektedir.

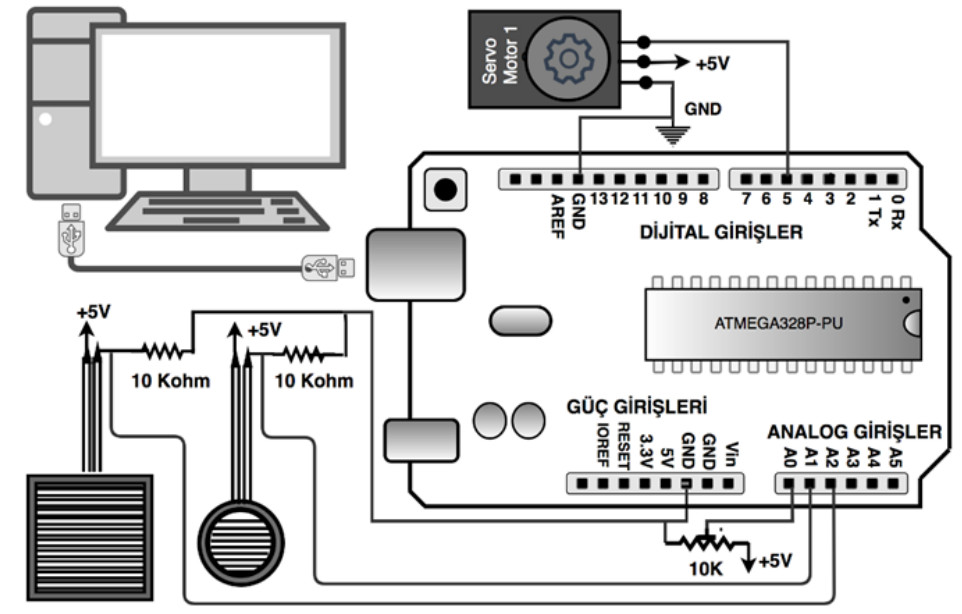

Şekil 5. Robot elin 1 parmağının, mikrodenetleyici tabanlı kontrol sisteminin elektronik donanım yapısı

\subsection{Bulanık mantık kontrol yapısı}

Sistem MIMO (çok girdili ve çok çıktılı) yapıya sahiptir. Bu tip bir sistem için doğrusal bir model oluşturularak kontrolünü gerçekleştirmek oldukça zordur. Ayrıca robot el ile nesnelere dokunmak, tutmak ve deforme olmasını göz ardı ederek kavramak gibi farklı hareketler yapılması ve bu hareket formları olușturulurken kuvvet sensörlerinden alınan geri bildirimler de kullanılarak hareket profilleri için uygun girdinin olușturulması oldukça karmașlk ve uzmanlık gerektiren bir konudur. 1965 yılında Zadeh tarafından geliştirilen bulanık mantık yöntemi ile kontrol sisteminin tasarımı bu problem için oldukça etkin bir çözüm yoludur. Bulanık mantık, probleme ait matematiksel olarak muğlaklığı temsil etmek ve biçimsel yapıya kavuşturulmuș araçlar sağlamak için tasarlanmıştır[28].
Bulanık mantık; sisteme özel, belirli uygulamalar için oldukça iyi performans sağlamaktadır [29]. Bu sebeple sistem kontrolünde bulanık mantık tabanlı kontrolcü kullanılmıştır. Tasarlanan kullanıcı temelli, bulanık mantık karar destek sistemi; kullanıcı komutu ve kuvvet geri bildirimi ile kendi kendine kavrama işlemine karar verebilen, adaptif bir kavrama yeteneğine sahiptir. Geliștirilen sistemde; robot el nesneyi kavramaya bașladığında kuvvet sensörü verileri mikrodenetleyiciye gönderilmektedir, ayrıca kullanıcıdan da bir kontrol ișareti alınmaktadır. Gelen veriler doğrultusunda bilgiler bulanık mantık kontrolör ile değerlendirilmektedir. Değerlendirme sonucunda servo motorlara hareket komutu verilerek nesnenin uygun kuvvette kavranması sağlanmaktadır. 
DEU FMD 21(62), 433-447, 2019

2.5. Kuvvet kontrolü için uygulanan bulanık mantık karar yapısı

Robot el sisteminin hareket kontrolü servo motorlarla yapılmakta olup, kavrayıcı uzuvlara kuvvet sensörleri yerleștirilerek, tutulan nesneye uygulanan kuvvetin ölçülmesi ve geri besleme yapılabilmesi sağlanmaktadır. Kullanıcı tarafindan farklı kavrama komutlarının gönderilebilmesi için ise potansiyometre kullanılmıştır. Potansiyometreden gönderilen sinyal doğrultusunda sistem kavrama kuvvetini belirlemektedir. Her parmak için bulanık mantık kullanılarak, potansiyometre ve kuvvet sensörü verileri ile kuvvet geri beslemeli kontrolcü geliștirilmiștir. Sekil $6^{\prime} \mathrm{da}$ işaret parmağı için oluşturulan bulanık kontrolcü sisteminin blok diyagramı sunulmaktadır.

$\mathrm{Bu}$ sistemde robot el üzerinde bulunan kuvvet sensör verileri ile kullanıcıdan gelen komut doğrultusunda parmakların açılması veya kapanması için servo motorlara uygun PWM (dalga genişlik modülü) sinyali gönderilerek açı kontrolü yapılmaktadır. Gönderilecek olan PWM sinyaline bulanık mantık kontrolör ile karar verilmektedir. Bu sayede kullanıcı temelli, kuvvet geri beslemesiyle parmaklarını kuvvete göre nesneye uyarlayan akıllı bir sistem geliştirilmiştir.

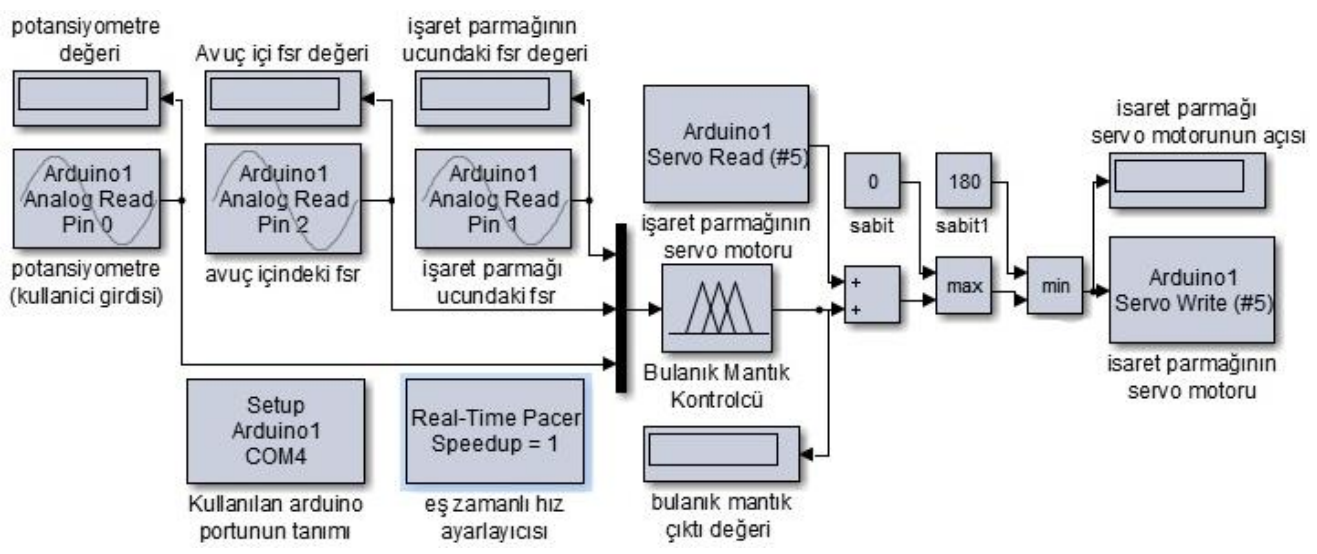

Şekil 6. Geliştirilen kontrol sisteminin blok diyagramı

\subsection{Tasarlanan bulanık mantık kontrolörünün özellikleri ve yapısı}

Tasarlanan bulanık mantık kontrolör her bir parmak için 2 sensör ve 1 kullanıcı sinyali olmak üzere 3 girdiye göre karar vermekte olup 1 çlktı üretmektedir. Sistemde kuvvet kontrolünün sağlanması için konum kontrolü yapılmaktadır. Tablo 2 ve Tablo 3'te Bulanık mantık kontrolör için oluşturulan dilsel kural tabloları verilmektedir. Dilsel kural tablosu kullanıcı temelli oluşturulmuş ve 125 kural tanımı yapılmıștır. Tablolara bakıldığında sistem durumu önce kuvvet sensöründen gelen verilere göre karar almakta, ardından kullanıcıdan gelen veri ile gerekli kontrol sinyalini göndermektedir.

Okunan sensör değerleri bulanık mantık kural tablosunda: az, az-orta, orta, çok-orta ve çok olmak üzere 5 girdi üyelik kümesinde tanımlanmıstır. Tablo 2'de sunulan kural tablosunda: parmak ucundaki sensör ve avuç içerisindeki sensör üyelik kümesi değerlerine göre sırasıyla D1; az ve az, az ve az-orta durumunu D2;az ve orta, az-orta ve az-orta, azorta ve orta, çok-orta ve az durumunu, D3; azorta ve çok-orta, orta ve orta, çok ve az durumunu, D4: çok ve az-orta, çok-orta ve orta, orta ve çok, çok-orta ve çok-orta durumunu, D5: çok ve çok-orta, çok ve çok durumunu temsil etmektedir. Tablo 3'te sunulan girdilere göre çıtı üyelik kümeleri dilsel olarak: NB; negatifbüyük, NO; negatif orta, NK; negatif-küçük, S; sıfır, PK; pozitif-küçük, PO; pozitif-orta, PB; pozitif-büyük șeklinde tanımlanmıștır. 
Tablo 2. Kural tablosu 1

\begin{tabular}{|c|c|c|c|c|c|c|}
\hline \multirow{7}{*}{ 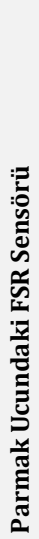 } & \multicolumn{6}{|c|}{ Avuç İçindeki FSR Sensörü } \\
\hline & & Az & $\begin{array}{l}\text { Az- } \\
\text { Orta }\end{array}$ & Orta & $\begin{array}{l}\text { Çok- } \\
\text { Orta }\end{array}$ & Çok \\
\hline & $\mathbf{A z}$ & D1 & D1 & D2 & D2 & D3 \\
\hline & $\begin{array}{l}\text { Az- } \\
\text { Orta }\end{array}$ & D1 & D2 & D2 & D3 & D4 \\
\hline & Orta & D2 & D2 & D3 & D4 & D4 \\
\hline & $\begin{array}{l}\text { Çok- } \\
\text { Orta }\end{array}$ & D2 & D3 & D4 & D4 & D5 \\
\hline & Çok & D3 & D4 & D4 & D5 & D5 \\
\hline
\end{tabular}

Tablo 3. Kural tablosu 2

\begin{tabular}{|c|c|c|c|c|c|c|}
\hline \multirow{7}{*}{ 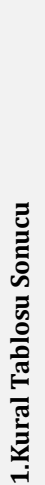 } & \multicolumn{6}{|c|}{ Kullanıcıdan Gelen Komut } \\
\hline & & Bırak & $\begin{array}{l}\text { Hafif } \\
\text {-Tut }\end{array}$ & Tut & $\begin{array}{l}\text { Hafif } \\
\text {-Sık }\end{array}$ & Sik \\
\hline & D1 & NK & PK & PO & PB & PB \\
\hline & D2 & $\mathrm{NK}$ & $S$ & PK & PO & PB \\
\hline & D3 & NO & $\mathrm{NK}$ & S & PK & PO \\
\hline & D4 & NB & NO & NK & $S$ & PK \\
\hline & D5 & NB & NB & NO & NK & S \\
\hline
\end{tabular}

Bulanık mantık kontrol sisteminde Mamdani bulanık çıkarım sistemi (FIS) tanımlanmıştır. FIS sistemi 3 girdi ve 1 çıktı üyelik fonksiyonundan oluşmaktadır. FIS sisteminin üyelik fonksiyonları Şekil 8, Şekil 9, Şekil 10 ve Şekil 11'de gösterilmiştir. Üyelik fonksiyonu olarak üçgen üyelik fonksiyonu seçilmiştir. Üçgen üyelik fonksiyonu, karar vericilerin kullanımı ve hesaplaması için kolay olması sebebiyle tercih edilmiștir[30]. Ayrıca girdi ve çıktılar üzerinde hesaplama basitliği nedeniyle üçgen, bulanık küme olarak kabul edilmiştir. Üçgen üyelik fonksiyonu Şekil 7'de gösterilmekte ve Denklem 3'te matematiksel olarak ifade edilmektedir [31].

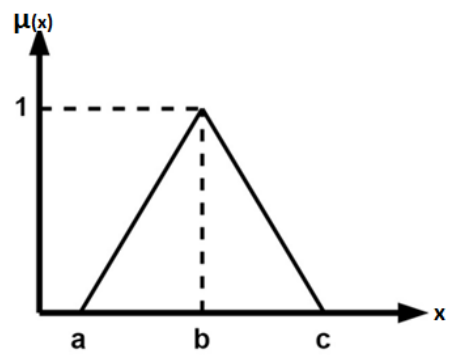

Şekil 7. Üçgen üyelik fonksiyonu

$\mu_{A}(x)=\left\{\begin{array}{ccc}a \leq x<b & \rightarrow & \frac{(x-a)}{(b-a)} \\ b \leq x \leq c & \rightarrow & \frac{(c-x)}{(c-b)} \\ x<\text { a veya } x>c & \rightarrow & 0\end{array}\right.$

Denklem 3'te $\boldsymbol{\mu}_{\boldsymbol{A}}$ üyelik derecesi, a başlangıç sınır değeri, c bitiş sınır değeri ve b en çok üyelik derecesine sahip olunan noktadır.

Kuvvet sensörü üzerine $0-600 \mathrm{~g}$ aralı̆̆ında kuvvet uygulanarak test edilmiştir. $\mathrm{Bu}$ test sonucunda 0-600 g kuvvet aralığına karşılık mikrodenetleyici tarafından 0-850 aralığında sayısal değerler elde edilmiștir. Elde edilen sayısal değerler bulanık mantık girdi üyelik kümelerinin parametrelerinin tanımlanmasında kullanılmıştır. $\mathrm{Bu}$ parametreler ve kuvvet karşılıkları Tablo 4'te sunulmuştur. Kullanıcı tarafından gönderilen kontrol sinyalinin girdi üyelik kümesi parametreleri Tablo 5'te, bulanık mantık çıktı üyelik kümesi parametreleri Tablo 6'da sunulmuştur. Tablo 5'te bulunan kullanıcı kontrol sinyali girdi üyelik kümesi parametreleri bir potansiyometreden elde edilen dijital değerler doğrultusunda tanımlanmıştır. Potansiyometreden 0 ile 1023 arasında lineer bir șekilde değișen dijital değerler elde edilmekte ve tablo 5 'te bulunan parametrelerin tanımlanmasında, elde edilen bu dijital değer aralığı, eşit değer aralıklarıyla kullanılmıştır. 
Tablo 4. Parmaktaki ve avuç içindeki FSR'nin girdi üyelik kümesi parametreleri

\begin{tabular}{|c|c|c|}
\hline $\begin{array}{l}\text { Parmaktaki } \\
\text { ve Avuç } \\
\text { İçindeki } \\
\text { FSR'nin Girdi } \\
\text { Üyelik Küme } \\
\text { İsimleri }\end{array}$ & $\begin{array}{l}\text { Okunan Dijital } \\
\text { Değerlere } \\
\text { Karşılık Gelen } \\
\text { Kuvvet (g) }\end{array}$ & $\begin{array}{l}\text { Okunan } \\
\text { Dijital Değere } \\
\text { Göre Üyelik } \\
\text { Kümesi } \\
\text { Parametreleri } \\
{[0-1023]}\end{array}$ \\
\hline $\mathbf{A z}$ & {$\left[\begin{array}{lll}0 & 0 & 150\end{array}\right]$} & {$\left[\begin{array}{lll}0 & 0 & 360\end{array}\right]$} \\
\hline Az-Orta & {$\left[\begin{array}{lll}0 & 150 & 300\end{array}\right]$} & {$\left[\begin{array}{llll}0 & 360 & 680\end{array}\right]$} \\
\hline Orta & {$\left[\begin{array}{llll}150 & 300 & 450]\end{array}\right.$} & $\begin{array}{ll}{[360} & 680 \\
795] & \end{array}$ \\
\hline Çok-Orta & {$\left[\begin{array}{llll}300 & 450 & 600\end{array}\right]$} & $\begin{array}{l}{[680} \\
850]\end{array}$ \\
\hline Çok & {$\left[\begin{array}{llll}450 & 600 & 600\end{array}\right]$} & $\begin{array}{l}{[795} \\
850]\end{array}$ \\
\hline
\end{tabular}

Tablo 5. Kullanıcı kontrol sinyalinin girdi üyelik kümesi parametreleri

\begin{tabular}{|c|c|}
\hline $\begin{array}{l}\text { Kontrol Sinyalinin } \\
\text { Girdi Üyelik Küme } \\
\text { İsimleri }\end{array}$ & $\begin{array}{l}\text { Tanımlanan Girdi Üyelik } \\
\text { Küme Parametreleri }\end{array}$ \\
\hline Bırak & {$\left[\begin{array}{lll}0 & 0 & 256\end{array}\right]$} \\
\hline Hafif Tut & {$\left[\begin{array}{lll}0 & 256 & 512\end{array}\right]$} \\
\hline Tut & [256 512 768] \\
\hline Hafif Sık & [512 768 1023] \\
\hline Sik & {$\left[\begin{array}{llll}768 & 1023 & 1023\end{array}\right]$} \\
\hline
\end{tabular}

Tablo 6. Servo motorun çıktı üyelik kümesi parametreleri

\begin{tabular}{|l|l|}
\hline $\begin{array}{l}\text { Servo Motorun } \\
\text { Çıktı Üyelik Küme } \\
\text { İsimleri }\end{array}$ & $\begin{array}{l}\text { Tanımlanan Çıktı Üyelik } \\
\text { Küme Parametreleri }\end{array}$ \\
\hline Negatif Büyük (NB) & {$\left[\begin{array}{lll|}-6 & -6 & -4\end{array}\right]$} \\
\hline Negatif Orta (NO) & {$\left[\begin{array}{lll}-6 & -4 & -2\end{array}\right]$} \\
\hline Negatif Küçük (NK) & {$\left[\begin{array}{lll}-4 & -2 & 0\end{array}\right]$} \\
\hline Sıfır (S) & {$\left[\begin{array}{lll}-2 & 0 & 2\end{array}\right]$} \\
\hline Pozitif Küçük (PK) & {$\left[\begin{array}{lll}0 & 2 & 4\end{array}\right]$} \\
\hline Pozitif Orta (PO) & {$\left[\begin{array}{lll}2 & 4\end{array}\right]$} \\
\hline Pozitif Büyük (PB) & {$\left[\begin{array}{lll}4 & 6 & 6\end{array}\right]$} \\
\hline
\end{tabular}

Kuvvete göre kuvvet sensörlerinin girdi üyelik fonksiyonu parametreleri 150 gramlı aralıklarla belirlenmiştir. Şekil 8 ve 9'da gösterilen girdi üyelik fonksiyonlarının sınırları robot el üzerinde kullanılan kuvvet sensörleri tarafından ölçülen ve mikrodenetleyici tarafından elde edilen dijital değerler doğrultusunda tanımlanmıştır. Ancak kuvvete göre kuvvet sensöründen elde edilen dijital değerlerin lineer olmaması sebebiyle üyelik fonksiyonlarının parametre aralıkları eşit değildir.

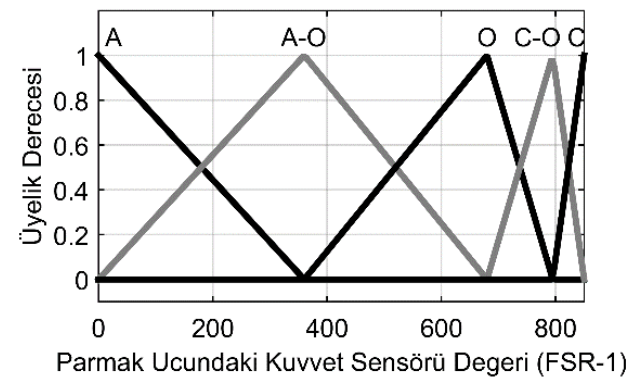

Şekil 8. Parmak ucundaki kuvvet sensörünün üyelik fonksiyonu

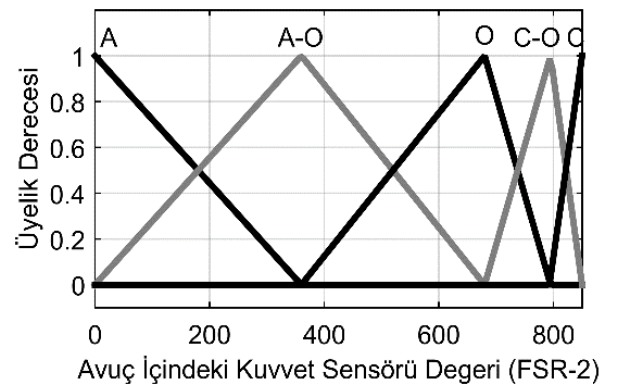

Şekil 9. Avuç içindek kuvvet sensörünün üyelik fonksiyonu

Şekil 10'da kullanıcıdan gelen kontrol sinyalinin girdi üyelik fonksiyonu gösterilmektedir. Kontrol sistemi kullanıcı temelli bir sistem olup, kullanıcının hatası minimize edilmek istenmektedir. Şekil 11'de ise sistemin çlktısının üyelik fonksiyonu gösterilmektedir. Sistemin çıktısında kuvvet kontrolü için servo motorun kaç derece açı ile dönmesi gerektiğine karar verilmektedir. 


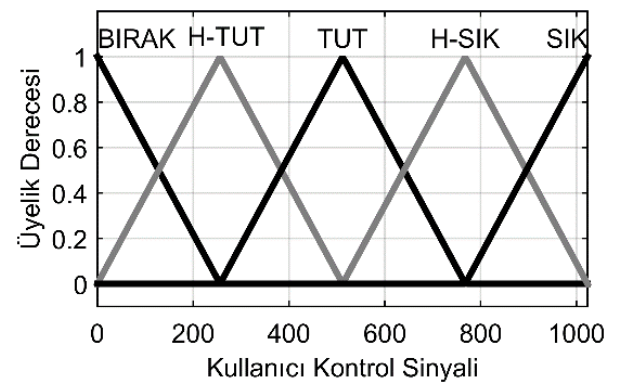

Şekil 10. Kullanıcıdan gelen kontrol sinyalinin üyelik fonksiyonu

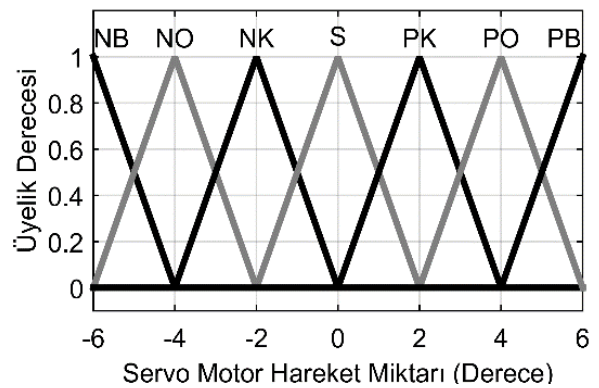

Şekil 11. Servo motorun hareket miktarı üyelik fonksiyonu

Girdi üyelik fonksiyonları ile çıkıș üyelik fonksiyonu ağırlı merkezi yöntemi ile hesaplanmıștır ve uygulanacak olan konum değișim miktarı elde edilmiștir. Servo motor için elde edilen konum değişim miktarının yüzey grafikleri: Șekil 12, Șekil 13 ve Șekil 14'te gösterilmektedir.

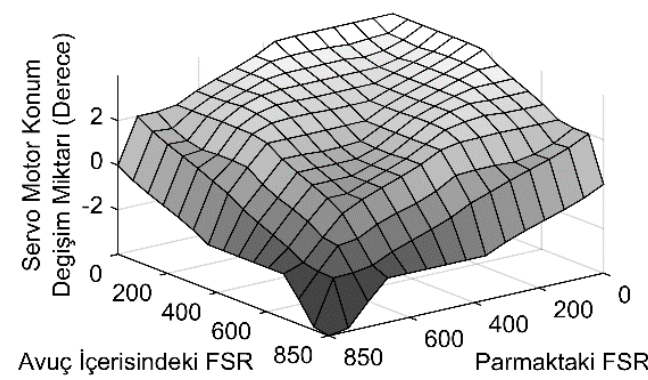

Şekil 12. Avuç içerisindeki ve parmaktaki kuvvet sensörünün değeri ve servo motor konum değișim miktarının bulanık mantık yüzey grafiği

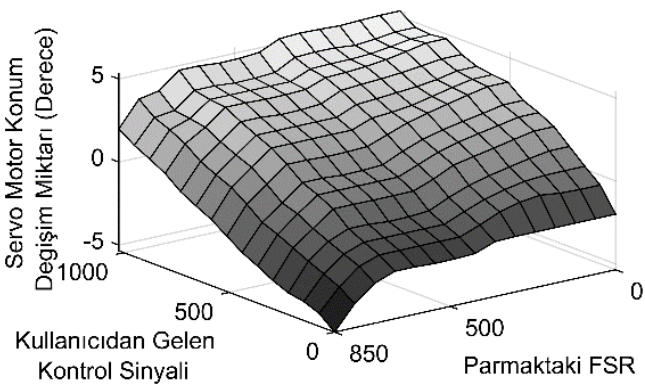

Şekil 13. Kullanıcıdan gelen kontrol sinyali, parmaktaki kuvvet sensörünün değeri ve servo motor konum değișim miktarının bulanık mantık yüzey grafiği

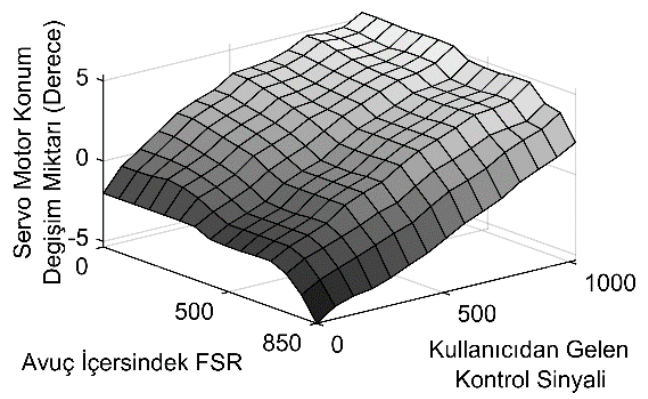

Șekil 14. Avuç içerisindeki kuvvet sensörünün değeri, kullanıcıdan gelen kontrol sinyali ve servo motor konum değişim miktarının bulanık mantık yüzey grafiği

\section{Bulgular}

Geliștirilen kontrol sistemi kullanıcı temelli oluşturulmuş olup, kullanıcıdan gönderilen sinyal doğrultusunda kavrama işlemleri gerçekleştirilmektedir. Nesnenin kavranmasında; bırak, hafif-tut, tut, hafif-sık ve sık komutları tanımlanmış ve uygulanmıştır. Hafif-tut komutunda nesneye düşük kuvvet uygulanarak nesnenin kavranması istenilmektedir, tut komutunda ise nesneye zarar vermeden, stabil bir kavrama sağlanması amaçlanmaktadır. Hafif sık komutunda nesneye tut komutuna göre daha fazla kuvvet uygulanarak nesnenin kavranmasının sağlanması, sık komutunda ise nesneye yüksek kuvvet uygulayarak nesnenin kavranması istenmektedir. Brrak komutunda ise robot elin parmaklarının açılarak nesnenin bırakılması amaçlanmaktadır. Bu amaçlar doğrultusunda, bir karar destek sistemi tasarlanmış ve robot 
elin nesneleri kavramasında hassas kuvvet kontrolü sağlanmıștır.

Tasarlanan karar destek sistemi ile robot el kontrol edilmiș ve farklı kavrama komutlarında nesneye uygulanan kuvvet değișiminin gözlemlenebilmesi için nesne olarak karton bir bardak kullanılmıștır. Deney sonucunda robot elin bir parmağı için elde edilen grafikler Şekil 15 'te sunulmuștur. Sistemde uygulanan kontrol sinyali ile parmağ motorun konumu Şekil 15a'da parmak ucu ve avuç içi sensörlerinden alınan ölçüm sonuçları ise Şekil 15b'de sunulmaktadır. Şekil 15 'te, 0 ile 18 (s) zaman aralığında, robot ele bırak, tut,hafif sık ve sık kavrama komutları gönderilmiştir. $\mathrm{Bu}$ komutlar doğrultusunda, robot el karton bardağı farklı kuvvet aralıklarında kavramıștır. $\mathrm{Bu}$ kavrama işlemleri sonucunda elde edilen görseller şekil 16'da sunulmaktadır. Başlangıçta Şekil 16a 'da robot ele birak komutu uygulanmaktadır. Bu sebeple robot el açıktır. Şekil 16b 'de robot el tut komutunu uygulamakta ve karton bardak zarar görmeden kavranmıștır. Şekil 16c 'de robot ele hafif sık komutu gönderilmiş, robot el nesneyi tut komutuna göre daha yüksek kuvvetle kavramıș ve bu sebeple karton bardak deforme olmuștur. Sekil 16d'de ise robot ele slk komutu gönderilmiştir. Sık komutu doğrultusunda nesne daha yüksek kuvvetle kavranmış ve hafif sık komutundaki duruma göre göre daha fazla deforme olmuştur. Grafik ve şekillerde de görüldügü üzere kontrol sistemi kullanıcı

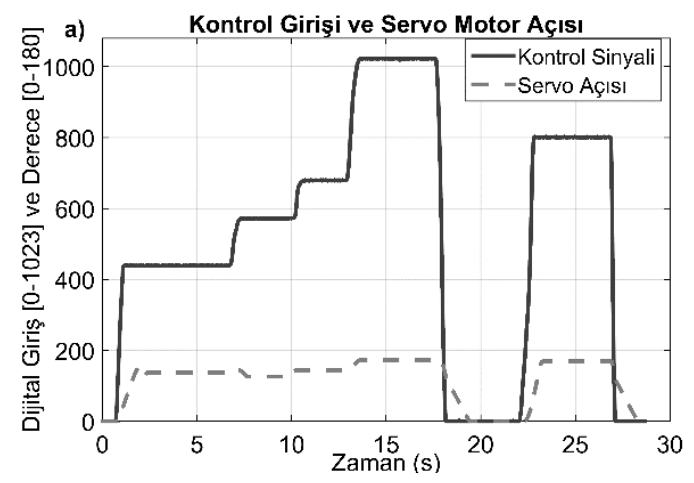

komutu doğrultusunda farklı kavrama komutlarını bașarı ile yerine getirebilmektedir.

Kontrol sistemi; avuç içerisine yerleștirilen nesnenin üzerine uygulanacak kuvveti, parmakların konumunu değiştirerek belirlemektedir. Robot eli başlangıçta aktif hale getirecek ve hafif tut, tut, hafif sık, sık, birak komutlarını gönderecek kullanıcı kontrol sinyali bir potansiyometre ile üretilmektedir. Kullanıcı bu potansiyometre üzerinden üretilen analog sinyal yardımıyla robot elin nesneleri kavraması sırasında uygulayacağı kuvvet miktarını tanımlamaktadır. Oluşturulan bulanık mantık kontrol yapısı; potansiyometreden 01023 arağında okunan dijital sinyali değerlendirme aşamasında kullanmaktadır. Böylece robot elin nesneyi kavrama esnasinda uygulaması gereken kuvvetin belirlenmesi için kontrolcüye bilgi sağlamaktadır. Bu bilgi ile uygulanacak kuvvet; az, az-orta, orta, çok-orta veya çok olarak belirlenmektedir. Ölçüm sonuçları ile kuvvet sensörleri için bulanık mantık üyelik kümelerinde tanımlanan parametre sınırları bölüm 2.6.'da Tablo 4'te sunulmuştur. Parmakların nesne ile temas anında ölçülen kuvvet degeri bulanık mantıkla oluşturulan karar destek sistemi tarafindan değerlendirilmektedir. Kontrol sinyalinin durumuna göre kuvvet ölçüm sonucu istenilen değere geldiğinde servo motor durdurularak nesneye uygulanan kuvvetin sabit kalması sağlanmaktadır.

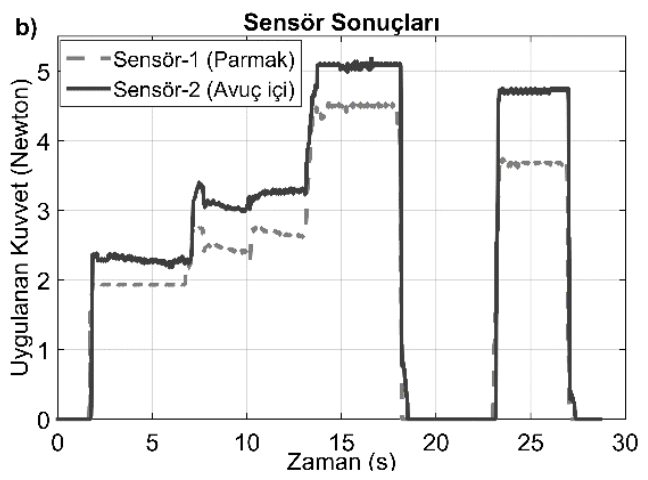

Şekil 15. Robot elin tek parmağı için üretilen kontrol sinyali ile ölçüm sonuçları 


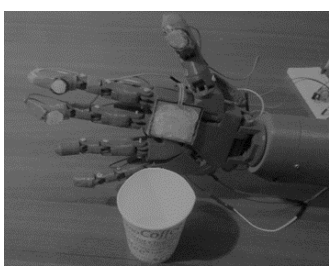

Şekil 16a. Robot ele birak komutunun uygulanması

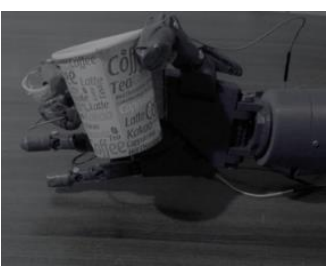

Şekil 16b. Robot ele tut komutunun uygulanması

Farklı kontrol sinyali değerlerindeki durumları gösterebilmek için robot ele, kontrol sinyali olarak rampa girdisi uygulanmıștır. Rampa girdisinin değeri, elde edilen servo motor konumu ve ölçülen sensör sonuçları Şekil 17'de sunulmuştur. Rampa girdisinin değeri referans değer olup, bu değer ile nesneye uygulanacak kuvvet miktarına karar verilmektedir. Sistem çalıştırılıp rampa girdisi uygulandığında; başlangıçta bulanık mantık kontrolör bırak komutunu değerlendirmiştir. 1. bölgede servo motor sifir derece konumunda ve sensörlerden gelen veriler sıfır olduğu için sistem önce yanıtsız kalmıştır. Rampa girdisinin değeri artmaya başlayıp hafif-tut komutu devreye girdiğinde; servo motora uygun sinyal gönderilerek parmak kapanmaya bașlamıștır. Nesne kavranırken devamlı bulanık mantık kontrolör sensör verilerini ve rampa girdisini değerlendirmiștir. Șekil 17'de 2. bölgede görüldüğü üzere; hafif-tut komutu doğrultusunda nesnenin, bulanık mantık kontrolör tarafından elde edilen uygun kuvvet aralıklarında sabit kuvvetle kavranması sağlanmıștır. $\mathrm{Bu}$ sayede nesneye daha fazla kuvvet uygulanması engellenmiştir. Rampa girdisinin değeri artıp tut komutu devreye girdiğinde ise: Sekil $17^{\prime}$ de 3. Bölgede tut komutu doğrultusunda bulanık mantık kontrolör tarafından belirlenen kuvvet aralıklarında nesnenin stabil bir şekilde kavrandığı görülmektedir. Rampa girdisi hafif sık komutunu gönderdiğinde: nesnenin bulanık mantık kontrolör tarafından belirlenen uygun kuvvet aralığında kavranması için servo motora bulanık mantık kontrolör tarafindan hesaplanan kontrol sinyali gönderilmiștir. Ve Sekil 17'de 4. bölgede görüldüğ̈ gibi, nesnenin tut komutuna

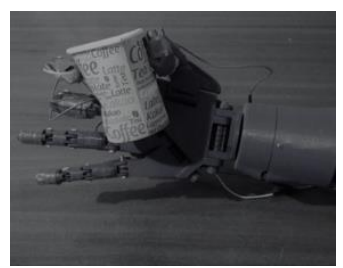

Sekil 16c. Robot ele hafif sik komutunun uygulanması

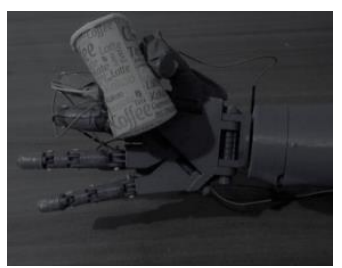

Sekil 16d. Robot ele slk komutunun uygulanması göre daha yüksek kuvvete kavranması sağlanmıștır. Rampa girdisinin değeri artıp sık komutu devreye girdiğinde ise; motora gönderilen sinyal doğrultusunda servo motorun torku artmış ve nesne daha yüksek kuvvetle kavranmaya başlamıştır. Sık komutu doğrultusunda uygulanan kuvvet miktarı ve servo motorun konum değişimi Şekil 17 'de 5 . bölgede gösterilmektedir. 17'de görüldüğü üzere rampa girdisinin değeri değiştikçe sistemin kavrama kuvvetinin değeri değișmektedir. Bulanık mantık kontrolör sistemi devamlı değerlendirerek servo motora gönderilecek sinyale karar vermektedir. Bu sinyal yardımıyla parmakların konumu ve nesneye uyguladıkları kuvvet miktarları değișmektedir. Olușturulan sistemde: bulanık mantık temelli kontrol sistemi yardımıyla robot el, gerekli hassasiyette nesneleri kavramaktadır. İnsanlar nesneleri kavramak için başlangıçta parmaklarının konumunu hızlı bir şekilde değiștirerek, nesneye teması sağlamaktadır. Daha sonra duyu organlarından gelen verilere göre, parmaklara daha yavaş ve küçük hareketler yaptırılarak nesneler uygun kuvvette, stabil bir şekilde kavranmaktadır. Robot elin parmakları açık durumdayken, kavrama komutlarından biri devreye girdiğinde parmaklar nesneye dokunana kadar bulanık mantık kontrolör servo motorun konumunu hızlı bir şekilde değiştirmesini sağlamakta ve parmaklar kapanmaktadır. Nesneye temas anından sonra ise bulanık mantık kontrolör servo motorun daha küçük miktarda konum değiștirmesini sağlayarak ya da mevcut konumunu sabit tutarak nesnenin kavranma kuvveti kontrol edilmektedir. 

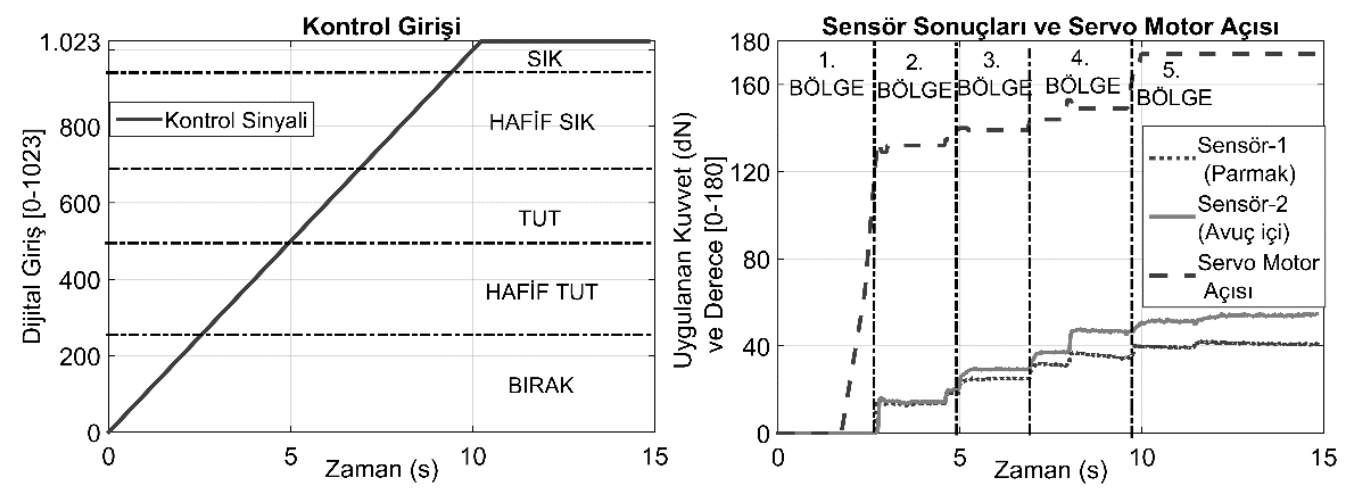

Şekil 17. Rampa girdisi ve sistem cevabı

\section{Tartışma ve Sonuç}

Sunulan çalışmada: 3 boyutlu yazıcı ile 5 parmaklı robot elin basımı yapılmıștır. Basımı ve montajı yapılan elin üzerine kuvvet sensörleri yerleştirilmiştir. Gerekli mekanik ve elektromekanik sistemlerinde el içerisine yerleştirilmesi ve elektronik donanımın bağlantılarının yapılması ile sistemin mekanik ve donanımsal yapısı tamamlanmıştır. Sistemde kullanılan kuvvet sensörleri üzerine ağırlık konularak dijital değerler elde edilmiș ve eğri uydurma yöntemi ile sensörün ağırlık-okunan dijital değer değişiminin denklemi elde edilmiştir. Oluşturulan sistemi kontrol etmek için bulanık mantık kullanılarak kontrol sistemi tasarlanmıştır. Tasarlanan kapalı kontrol sistemi her bir parmak için 2 sensör ve 1 kullanıcı sinyali olmak üzere 3 girdiye göre karar vermekte olup 1 çıtı üretmektedir. Bütün parmaklar için oluşturulan kontrol sistemi yapısı aynı olup, bu çalışmada robot elin bir parmağının kontrolü için oluşturulan yapı tanıtılmış ve deney sonuçları sunulmuştur.

Manipülatörler nesneleri kavrarken nesneye uyguladıkları kuvveti hassas bir șekilde kontrol etmeleri gerekmektedir. Aksi taktirde nesnelere

\section{Kaynakça}

[1] MICHALEC, R 2011. Modeling and control of multifingered dextrous manipulation for humanoid robot hands. Université Pierre et Marie Curie-Paris VI, PhD Thesis, 588s, Paris

[2] Boughdiri, R., Nasser, H., Bezine, H., M'Sirdi, N. K., Alimi, A. M., Naamane, A. 2012. Dynamic modeling and control of a multi-fingered robot hand for grasping task, Procedia Engineering, Vol. 41, p. 923931. DOI: 1 0.1016/j.proeng.2012.07.264

[3] Katibeha, F., Eghtesadb, M., Bazargan-Laric, Y. 2016 Dynamic modeling and control of a 4 DOF robotic finger using adaptive-robust and adaptive-neural zarar verilebilir. Kuvvet kontrolünün sağlanması, yaygın olarak kuvvet geri beslemesi ile çözümlenmektedir. Mevcut sistemlerin bir kısmı incelenmiş ve kuvvet geri beslemesine yönelik önerilen çözüm yollarının karmaşık ve çok fazla ișlem gerektirdiği görülmüștür. Sunulan çalışmada kuvvet geri beslemesi ile bulanık mantık kontrolcü tasarlanmış ve önerilen kontrol yapısıyla özellikle hassas nesnelerin kavranmasında karşılaşılan kuvvet belirsizlik probleminin çözülmesi amaçlanmıștır. Bulanık mantık kontrolcü ile lineer olmayan sensör verileri işlenerek, basit ve geniş uygulama alanına sahip bir kontrol sistemi geliștirilmiștir. Geliștirilen kontrolcü, kullanıcı sinyali doğrultusunda nesnelerin kavrama kuvvetine karar vermektedir. Nesnenin robot elden düşmeyeceği kadar çok, deforme olmayacağ $\breve{1}_{1}$ kadar az kuvvet hesaplanarak robot ele hassas ve kararlı kavrama özelliği kazandırılabilmektedir. Ayrıca elin kullanıcı sinyali ile nesneye yüksek, orta ya da düşük kuvvet uygulayarak kavrama yapabilmesi sağlanmaktadır. Elde edilen kuvvet kontrolü sayesinde robot elde oluşabilecek kontrol yetersizliği sonucu nesnenin zarar görmesi önlenebilecektir.

controllers, International Journal of Robotics, Vol. 4, No. 4, p. 51-61.

[4] Lin, L. R., Huang, H. P. 1996. Integrating fuzzy control of the dexterous National Taiwan University (NTU) hand., IEEE/ASME Transactions on Mechatronics, Vol. 1(3), p. 216-229. DOI: $10.1109 / 3516.537044$

[5] Yang, Y., Zhang, W., Xu, X., Hu, H., Hu, J. 2017. LIPSA hand: a novel underactuated hand with linearly parallel and self-adaptive grasp, In Mechanism and Machine Science, $10^{\text {th }}$ International Conference on Intelligent Robotics and Applications, 16-18 August, Wuhan ,China, 739-751. 


\section{DEU FMD 21(62), 433-447, 2019}

[6] Khakpour, H., Birglen, L. 2013. Numerical analysis of the grasp configuration of a planar 3-DOF linkage-driven underactuated finger, Journal of Computational and Nonlinear Dynamics, Vol. 8(2), p. 021010-1,021010-8. DOI: $10.1115 / 1.4007359$

[7] Argonne National Laboratory. 1949. Reactors: Modern-Day Alchemy Argonne National Laboratory. http://www.ne.anl.gov/About/modern-dayalchemy. (Erișim Tarihi:14.03. 2017).

[8] Devol, J. G. C. 1961 . U.S. Patent No. 2,988,237. Washington, DC: U.S. Patent and Trademark Office

[9] Devol, G. 1959. Robotic Industries Association "A Tribute To Joseph Engelberger". http://www.robotics.org/joseph-engelberger/ about.cfm (Erișim Tarihi: 14 Mart 2017).

[10] Hirose, S., Umetani, Y. 1978 . The development of soft gripper for the versatile robot hand, Mechanism and machine theory, Cilt. 13(3), s. 351-359. DOI: 10.1016/0094-114X(78)90059-9

[11] Bekey, G. A., Tomovic, R., Zeljkovic, I. 1990. Control architecture for the Belgrade/USC hand. In Dextrous robot hands. Springer, New York, NY. 136-149s.

[12] Yan, J., El-Baradie, M. A., Hashmi, M. S. J. 1992. The development of a robotic compliance control system, International Journal of Machine Tools and Manufacture, Cilt. 32(4), s. 477-486. DOI: 10.1016/0890-6955(92)90039-J

[13] Lin, L. R., Huang, H. P. 1998. NTU hand: A new design of dexterous hands, Journal of Mechanical Design, Cilt. 120(2), s. 282-292. DOI: 10.1115/1.2826970

[14] Fukaya, N., Toyama, S., Asfour, T., Dillmann, R. 2000. Design of the TUAT/Karlsruhe humanoid hand. In Intelligent Robots and Systems (IROS 2000). Proceedings. 2000 IEEE/RSJ International Conference, 30 Oct-5 Nov. ,Japan, Vol. 3, pp. 17541759.

[15] Butterfaß, J., Grebenstein, M., Liu, H., Hirzinger, G. 2001. DLR-Hand II: Next generation of a dextrous robot hand. In Robotics and Automation, 2001. Proceedings 2001 ICRA. IEEE International Conference on Vol. 1, 21-26 May, South Korea, pp. 109-114.

[16] Kawasaki, H., Komatsu, T., Uchiyama, K. 2002. Dexterous anthropomorphic robot hand with distributed tactile sensor: Gifu hand II., IEEE/ASME transactions on mechatronics, Cilt. 7(3), s. 296-303. DOI: 10.1109/TMECH.2002.802720

[17] Pons, J. L., Rocon, E., Ceres, R., Reynaerts, D., Saro, B., Levin, S., Van Moorleghem, W. 2004. The MANUSHAND dextrous robotics upper limb prosthesis: mechanical and manipulation aspects, Autonomous Robots, Cilt. 16(2), s. 143-163. DOI: 10.1023/B:AURO.0000016862.38337.f1

[18] Zollo, L., Roccella, S., Guglielmelli, E., Carrozza, M. C., Dario, P. 2007. Biomechatronic design and control of an anthropomorphic artificial hand for prosthetic and robotic applications, IEEE/ASME Transactions On Mechatronics, Cilt. 12(4), s.418-429. DOI: 10.1109/TMECH.2007.901936

[19] Liu, H., Meusel, P., Seitz, N., Willberg, B., Hirzinger, G., Jin, M. H., Xie, Z. W. 2007. The modular multisensory DLR-HIT-Hand, Mechanism and Machine Theory, Cilt. 42(5), s. 612-625. DOI: 10.1016/j.mechmachtheory.2006.04.013
[20] Kroemer, O. B., Detry, R., Piater, J., Peters, J. 2010. Combining active learning and reactive control for robot grasping, Robotics and Autonomous Systems, Cilt. 58(9), s.1105-1116. DOI: 10.1016/j.robot.2010.06.001

[21] Teng, M. C., Tsai, Y. J., Hsiao, C. C. 2013. Mechanical Design and Kinematic Analysis of a 10 DOF Robot Manipulator, IFAC Proceedings Volumes, Cilt. 46(5), s.301-306. DOI: 10.3182/20130410-3-CN2034.00022

[22] Chen, W., Xiong, C. 2016. On adaptive grasp with underactuated anthropomorphic hands, Journal of Bionic Engineering, Cilt. 13(1), s. 59-72. DOI: 10.1016/S1672-6529(14)60160-8

[23] Zaidi, L., Corrales, J. A., Bouzgarrou, B. C., Mezouar, Y., Sabourin, L. 2017. Model-based strategy for grasping 3D deformable objects using a multifingered robotic hand, Robotics and Autonomous Systems, Cilt. 95, s. 196-206. DOI: 10.1016/j.robot.2017.06.011

[24] Xu, S., Xu, Y., Xu, X. 2018. Structural design and kinematics analysis of SHU-hand II humanoid robotic hand. In IOP Conference Series: Materials Science and Engineering, 16-17 June, China, Vol. 394, No. 4, p. 042068.

[25] Uraz, C., Macit, Ș. 2018. Electroless Cu Plating on ABS Plastic by Using Environmentally Friendly Chemicals, Journal of Science and Engineering, Cilt. $20(59)$, s. 369-375. DOI: 10.21205/deufmd. 2018205930

[26] Langevin, G. 2012. Inmoov Open Source 3D printed life-size robot. http://inmoov.fr/hand-and-forarm/ (Erișim Tarihi: 19.03.2018).

[27] FSR 402 Data Sheet. 2010. http://www.trossenrobotics.com/productdocs/201 0-10-26-DataSheet-FSR402-Layout2.pdf (Erişim Tarihi: 03.06.2018).

[28] Türkbey, 0. 2003. Cok Amaçlı Makina Sıralama Problemi İçin Bir Bulanık Güçlü Metod, DEÜ Mühendislik Fakültesi, Fen Ve Mühendislik Dergisi, Cilt. 5, s.81-98.

[29] Kubat, C. 2014. MATLAB: Yapay Zeka ve Mühendislik Uygulamaları. Pusula yayınları

[30] Kaftan, İ., Balkan, E., Șalk, M. 2013. Bulanık Mantık (Fuzzy Logic) Ve Jeofizikte Kullanım Alanları: Sismoloji Örneği, DEÜ Mühendislik Fakültesi, Fen Ve Mühendislik Dergisi, Cilt. 15(2), s.15-29.

[31] Kaufmann, A., Gupta, M. M. 1988. Fuzzy mathematical models in engineering and management science, Elsevier Science Inc. 